\title{
Effects to Construction Project Management Impacted Circular Economic of Covid-19 Pandemic
}

\author{
Wali Noor Khan Paikan
}

Department of Architecture, Engineering Faculty, Shaikh Zayed University, Khost-Afghanistan

Corresponding author: walipaikan@gmail.com

Received: 23 Mar., 2021

Revised: 17 May, 2021

Accepted: 11 Jun., 2021

\begin{abstract}
COVID-19, social distance, self-isolation, quarantine, layoff, migraine prophylaxis, and many others have started to emerge as the globe's new vocabulary, not exempted from the construction sector. It is exactly a period since the modern world encountered the very last epidemic. Nevertheless, the most famous epidemic of disease known as Corona Virus Disease 2019 (COVID-19) was reported to have struck all peoples of the world within 4 months and proclaimed an epidemic in March 2020. This outbreak has impacted industries from all around the world, such as built-up asset procurement and facility management. Its influence has led to the use of creative and complex innovations in an outstanding way that can alter the direction of construction long just after coronavirus has been extinguished. This thesis examines the impact of COVID-19 using a quantitative approach on built asset acquisition and future prospects for the construction sector. For the information gathering, a survey was conducted out over the built asset acquisition practitioners. Architects, building, civil, electrical, and mechanical engineers, project managers and quantity surveyors received 71 questionnaires. For the study of the results, the program SPSS 25 (a social science statistical package) was used. From the result of the analyzing it's become clear of the project status that over 90 percent reported that their projects were impacted due the Pandemic. Nearly 51 percent of the participants suggested that their initiatives were partly halted due to the COVID-19, while up to 40 percent of the participants witnessed full stoppage. One of the participants disclosed that the proposals had been absolutely halted at the initial level and then turned into partial.
\end{abstract}

Keywords: Circular Economy, COVID-19 impact, construction, project management

HE globe got up to an alarming fact on $11^{\text {th }}$ March 2020 when the World Health Organisation (WHO) proclaimed the new virus called (COVID-19) a pandemic (Sohrabi, et al. 2020). The cases started in Wuhan, China and spread quickly to Europe, South Korea, Japan and the United States when they achieved universal magnitudes. Significant economic signs from various sources towards the official declaration of a pandemic, weeks ago, suggested that the world was leaning towards an unparalleled crisis in our era, if not in history of human (Gopinath, 2020). In series of revelatory reports (Daszak, 2012), Experts

How to cite this article: Paikan, W.N.K. (2021). Effects to Construction Project Management Impacted Circular Economic of Covid-19 Pandemic. IJASE., 9(01): 41-51. 
through technical cadres have long anticipated that a global pandemic is straining the global supply chains and demands elements, causing a cross-border economic catastrophe due to the increasingly integrated world in which we now live. According to both sources, the unfolding catastrophe caused by the pandemic surpassed the forecasts of those comments. At the time of writing, the epidemic infected more than 11000,000 people worldwide (Pourghasemi et al. 2020); disrupted livelihoods cost trillions of dollars, as the universal recession threatens (Naidoo \& Fresher, 2020). Countries around the world have adopted strict steps such as obligatory national lockdowns and border closures in attempts to separate cases and reduce the infection rate of the virus while reducing the pandemic (Mohammed, et al. 2021). There is no question that Coronavirus would have a lasting effect on the building industry as shown in Fig. 1 (Ward, 2020). As a result of the COVID-19 pandemic, building industry members, including founders, developers, contractors, subcontractors and supply chain suppliers, have endured differing degrees of impacts. In large part, the essence of the consequences and the magnitude of the implications depend on the position of both the relevant firms and the underlying programs. Direct impacts varied from the slowdown of supplies and labour available to suspensions and, in some situations, terminations of parties or programs as a whole. In certain states and cities, building operations remain in flux, depending on whether construction is classified as an important sector. Germany's economy will contract by 6.3 per cent in actual terms in 2020. The spring forecast due to the German government's, will come about 6.9 percentage points lesser than the growth rate that was for 2019. The coronavirus epidemic is dragging more than a decade of economic prosperity to an end. For German construction industry, Covid-19 may turn out to be the fourth big crisis of the in the past 40 years. The second oil crisis that was happened in 1980s and the effects of that crisis was decade-long downturn in overcapacity that accompanied the reconsolidation and the short weakening that happened during the financial catastrophe (Schober, 2020).

\section{COVID-19 crisis could mean more than a short-term reduction in revenue and margin - Need for companies to prepare for the future}

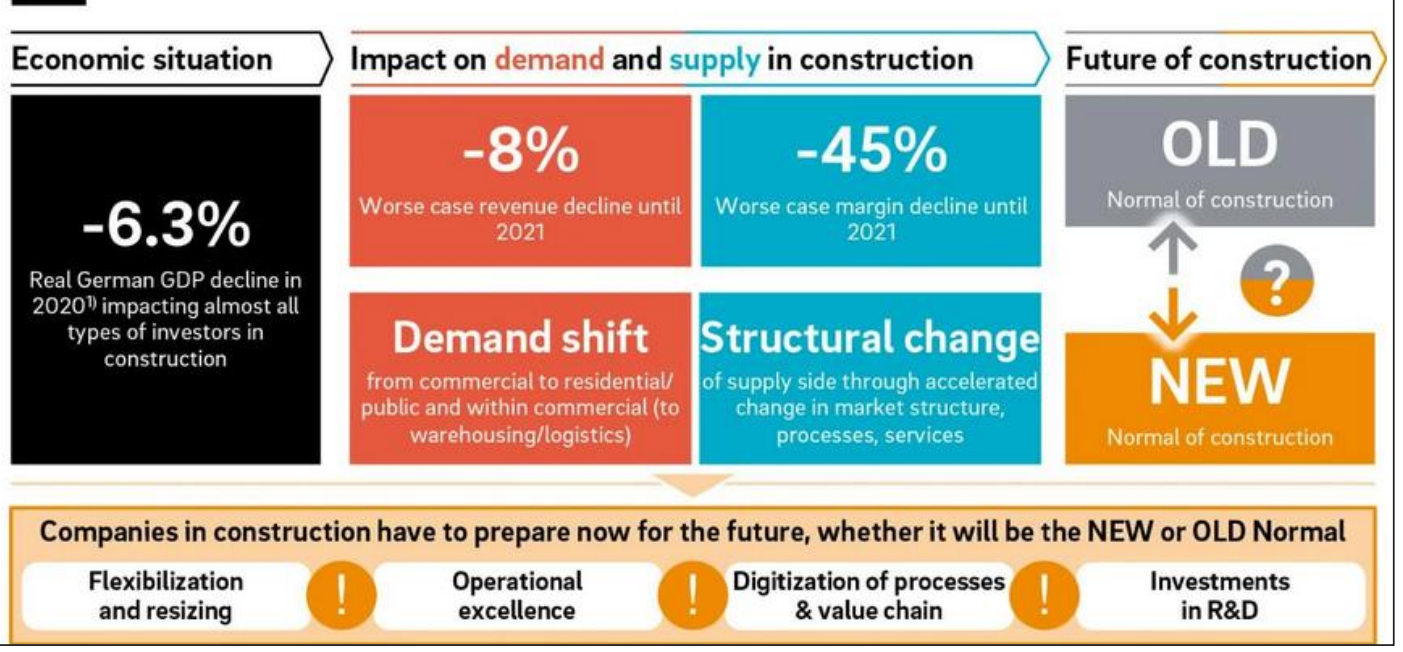

Fig. 1: Shows the covid-19 impact on the construction industry

Sources: German federal government: Ronald Berger 
As a result, the COVID-19 crisis has contributed to the need for industry participants to solve both short-term and long-term market issues, as well as to establish project-by-project strategies in the face of a new global and national climate. The full magnitude and scope of the improvements necessary to resolve the pandemic problems that is unclear yet. This study is expected to continue to develop until a vaccine or other curative steps are internationally in effect. Such new realities impact almost all parts of the building procedure, and particularly problems such as contract or schedule notifications for default, scheduling and modifications; suspension, termination and reinstatement of projects; compliance with Occupational Safety and Health Administration (OSHA) and worker safety; management of workforce; delays and impacts of content, subcontractor and supply chain; Benefit assessment and insurance; claims reduction or, alternatively, claims management; and dispute resolution (Chivilo, Fonte, \& Koger, 2020).

The idea of a circular economy has been discussed by several economies looking to resolve the waste problem, like this year's host. A waste elimination scheme maintains the use of materials and regenerates natural systems. It stands in sharp contrast to the more common linear economy paradigm that, after a single usage, disposes of materials. For several, a change to this system will be a break from longstanding norms. Getting there is going to be a long and careful process. However, if applied successfully, a circular economy, or at least the ideas that shape its building blocks, leads not only to environmental issues but also to alleviating the immediate and long-term negative impact of pollution on the economy and people's well-being (Hew, 2020). Covid-19 could turn out to be the fourth huge crisis in the world construction industry in the last four decades as shown in the Fig. 2 (Schober, 2020).

\section{For the first time since the financial crisis 2008, the COVID-19 crisis is about to interrupt a long period of growth in construction markets}

\section{Real GDP1) and real construction output, Germany, 1980-2020 [EUR bn in prices of 2018]}

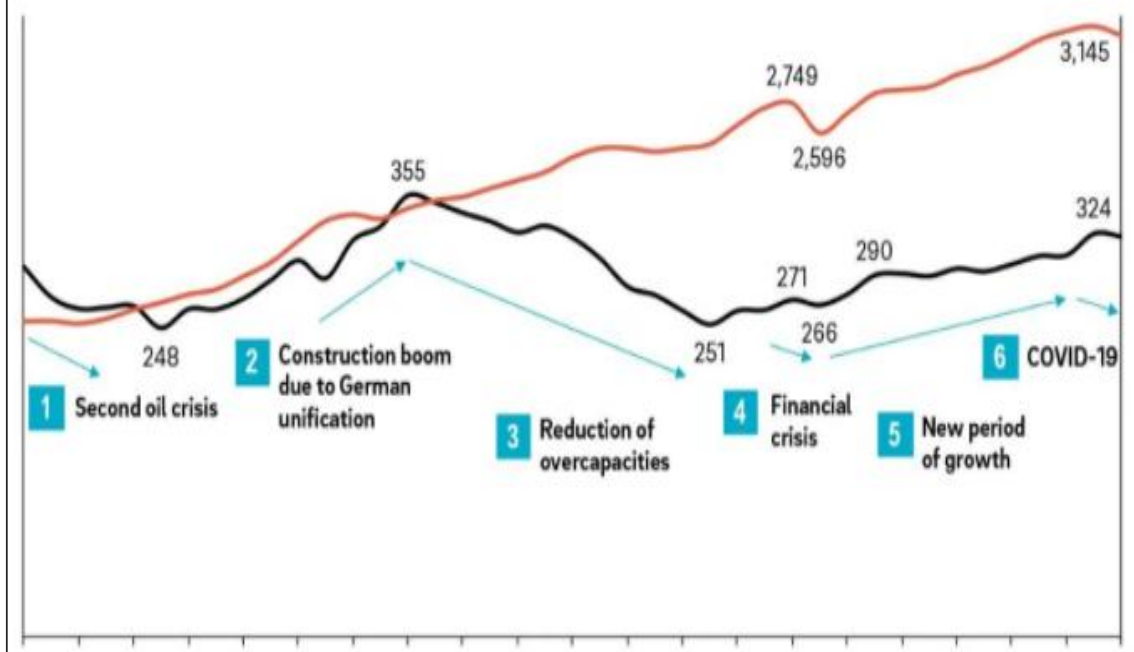

98019821984198619881990199219941996199820002002200420062008201020122014201620182020
$>$ During the last 40 years, periods of a duration of c.1 decade of overall positive and negative growth have alternated Since 2005 , the construction industry is again on a growth trajectory

Last economic crisis before the current COVID-related crisis the financial crisis - had a one time effect as negative impact could quickly be removed

Fig. 2: Shows the crisis impact on the construction industry 


\section{Literature Review}

As one of the goals for achieving a sustainable economy, the European Green Deal involves the construction sector by encouraging cleaner construction practices and upgrading the construction infrastructure, especially for social housing, hospitals and schools. In addition, the updating of green cities seeks to foster energy-efficient infrastructure, using circular architecture and digitalization (European Commission, 2019). Then, programs such as Buildings and Materials Banks (Górecki, NúñezCacho, Corpas-Iglesias, \& Molina, 2019), which consider buildings as "materials banks," are focused on recovering and the value of construction materials, using Building Information Modeling (BIM) to identify what materials can be saved, the amount of material used, and how to uninstall the building (Górecki, Núñez-Cacho, Corpas-Iglesias, \& Molina, 2019). Lopez-Ruiz et al. Moreover, according to five lifecycle phases, 14 methods for enforcing legislative and political CE structures are identified: (i) pre-development, (ii) construction and reconstruction, (iii) selection and delivery, (iv) end-of-life, and (v) recovery and development of materials. Preconstruction techniques are economic methods, waste management design, disassembly and deconstruction to avoid future environmental harm. The effect of using prefabricated components to promote deconstruction and creation of management plans for building and demolition waste (CDW) is also understood. In the building and reconstruction process, the implementation of site waste management plans (SWMPs) is key, as the waste at this point mostly comes from deteriorated materials, imprecise concrete components, or steel bar cut-offs, among others. Collection and delivery includes the methods of collection and segregation and transport systems. Selective deconstruction and deconstruction and dismantling audits are required at the end of existence. Finally, reuse, recycle, energy recovery, and backfilling to restore value from recycled materials in buildings are used in resource recovery and development.

\section{(a) Circular Economy Concept}

Sometime industrial economy refers to a Circular Economy that is regenerative the purpose and nature (Benton, 2015). It is intended to focus on green energies, to minimize the consumption energy, to avoid the use of hazardous materials and, by careful planning, to eliminate waste. CE's key feature is that the processing system is regenerative of inputs used, reducing the process's negative externalities. It may be claimed that regenerative by nature is a common concept. In addition, during processing, the key energy is green energy, which aims to minimize chemical waste. Several primary reasons support the proposal. Thus, the customer actually uses the product and the retailer is responsible for recycling the material to sell the sale of items and not the material. Customers may buy the use of a commodity and, when the product becomes redundant, it returns and renews. Reuse, in that sense, is a sign of good management. The 3R theory (reduction, reuse and recycling) aims to reduce the burden on the global stock of energy (Reike, Vermeulen \& Witjes, 2018). In the past, reuse was a tactic of scarcity and hunger, according to (Hirschnitz-GarbersAdrian, TanAlbrecht, \& Srebotnjak, 2015). Today, they are icons of good resource management.

The achievement of Circular Economy is determined by many variables. The most critical properties of goods or processes that enable them to be part of the supply chain are modularity, flexibility and adaptability (Seebacher \& Winkler, 2013). Due to emerging technology built by the transition of functions from biological systems, development systems will become more viable (Lepora, Verschure, \& Prescott, 2013). One of biomimetic' main problems (Gebeshuber, Gruber, \& Drack, 2009) concerns the 
transformation into a technical circumstance of the natural life cycle. The "cradle to cradle" hypothesis is an important theme of the Circular Economy as it aims to emulate nature, but with industrial products, imitating the biological recycling mechanism (Benton, 2015). However, all methods and products that can be bio-mimicked need to be analyzed.

\section{Research Methodology}

This research is for evaluating the COVID-19 pandemic positive and negative effects on the construction firms. This was done through the analysis of minimal literature from the desk research as the pandemic happened recently and an arena research through the gathering of main evidence from building professionals in all parts of the building industry which include Architecture, Civil, Mechanical, Electrical engineering respectively and also the construction project management and Quantity Surveying. With positive and negative viewpoints all the researchers agreed to pursue information internationally to consider the practitioners around the globe for acting as a platform for more study. As COVID-19 is a new pandemic and for this reason there was not enough literature testing for generating information. They i.e. who were participated in this research trained in the areas as following: planner or consultant, construction, customer or production firm. The organizational size of the participants was $<10$ staff (micro), 10-50 staff (small), 50-200 staff (medium) and $>200$ staff (micro), respectively (large). 5-10, 11-15 and $>15$ years are years of experience respectively. Although, the survey responses were collected from five continents across the world, including North America, Europe, Africa, Australia and Asia. The data that was primary produced were then analyzed using the SPSS 25.0 analytical method.

\section{(a) Sampling, Population and Questionnaire Survey}

Sampling is a critical technique for statistical research, which means choosing a few parts of a possible sample. This is to test or benefit about the population at a low-cost. Easy random sampling, usually referred to entails the arbitrary collection of the sample that comes from the sampling system which use random number and tables (Saunders, Lewis, \& AThornhill, 2009) or random number generator on the internet, such as Randomizer Inquire (Meng, 2013). Easy random sampling has been defined as an integral form of sampling, either used as a sampling technique itself or as a building block for more complicated sampling strategies. While Easy random sampling is commonly used in scholarly literature, the Easy random sampling guideline tends to be that each imaginable sample has the same chance of being picked without a specific description; however, the definition of "possible sample" may change over idiosyncratic sampling patterns. In this study, Easy random sampling is adopted to enter a wide domain of study as the topic is universal (i.e. COVID-19 pandemic). The survey field is focused on the building sector, and is a possible research sample for of stakeholder (Ott \& Longnecker, 2001) it clarified how the central limit theorem remains true in a naturally dispersed analysis sample as for replies. The central limit theorem is deemed valid or appropriate when the sample size is greater than or equal to thirty (30) (Ott \& Longnecker, 2001). As the central limit theorem holds true, the 71 responses obtained in this analysis are therefore considered appropriate. The questionnaire contains close-ended and open-ended questions with suggestions for different choices. The survey questionnaire is built online, hosted and shared in a goggle shape in the goggle trip. On specialist platforms such as LinkedIn and forums for construction companies, links to the goggle form are shared. The direct emails sent to the main built environment actors. The received responses were 71 totally. The survey questionnaire was grouped according to 
these subheadings: demographics, COVID-19 project standing, COVID-19 influences, as well as other comments. There is variation in the locations of the respondents, notably in terms of legislature and IT facilities to promote "work from home" and social distance enforcement. Responses from these points of view (government directives, judgments and support) are also measured qualitatively and solely. In the other hand, the stoppage of work and the importance of pandemic's effects/impacts is measured quantitatively. The qualitative section narrates the perceptions (lessons learned) and government decisions of respondents. In comparison, the quantitative section measures the value of variable scores and patterns. A 5-point Likert scale measures the importance depending on how important (RII $\bullet 0.70$ ) or mean $\bullet 3.5$ in a 5-point Likert scale is (Badu, Edwards, Owusu-Manu, \& Brown, 2012).

\section{(b) Data Analysis}

The data collected from the study, evaluated using descriptive statistics. This collected data is from five continents across sixteen countries of the respondents. To avoid a sloppy display of results, Figure 3 shows the respondents based distribution of these continents. The largest number of participants was 54.9 percent from Africa, followed by 22.5 percent from Asia, 18.3 percent from Europe, 2.8 percent from North America and 1.4 percent from Australia. The 16 countries participating are South Africa, England, Nigeria, Zambia, Scotland, Ireland, Barbados, Canada, Australia, Nepal, Indonesia, India United Arab Emirates, Saudi Arabia, Qatar, and Russia.

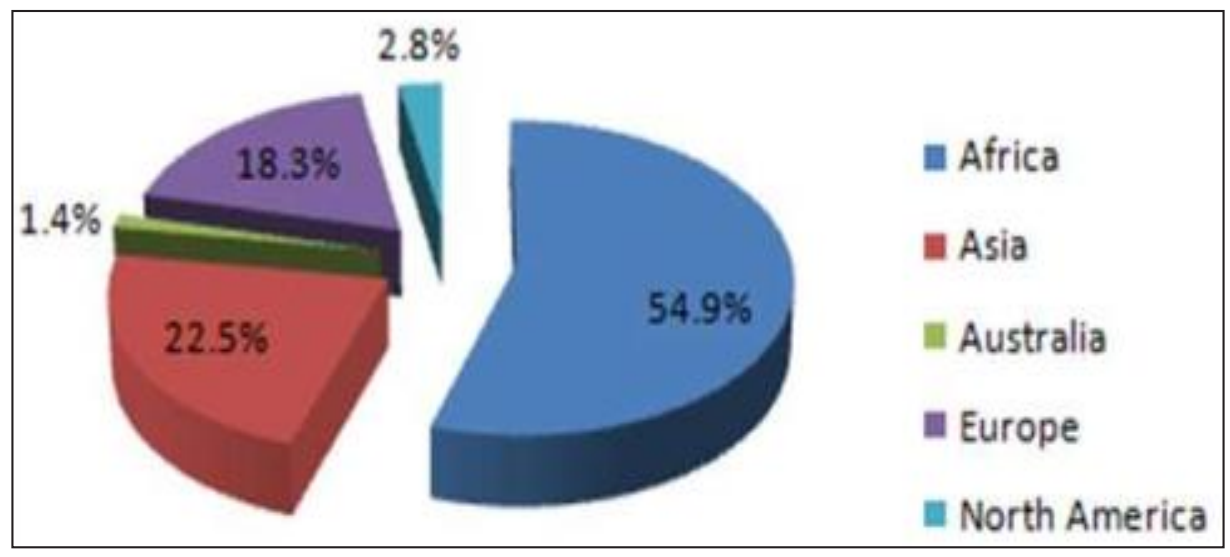

Fig. 3: Participants' country of operation

The distribution of respondents in Table 1 indicates that, given their educational backgrounds, the participants are qualified practitioners. As such, first and second degree holders are more than $90 \%$ of the participants for background studying. Necessary and true are considered. Furthermore, the study interest is the areas their interest specialty; they are (Architects, Project Managers, Civil Engineers, Construction workers and Quantity Surveyors). The participants that directly involved in projects are more than $80 \%$. Their job is design and construction in the firms rather than customers or governing power. In addition, the specialty areas of importance to the research; they are mainly specialists in the built environment (architects, structural engineers, supervisors of construction/projects and surveyors of quantity). Above 80 percent are architecture and development companies that are actively interested with projects rather than customers or law implementers. 
Table 1: Demographic information of the participants

\begin{tabular}{|c|c|c|c|}
\hline & Description & Number & Percentage $(\%)$ \\
\hline \multirow[t]{4}{*}{ Respondents Academic Qualification } & Higher National Diploma & 5 & 7.0 \\
\hline & First Degree & 21 & 29.6 \\
\hline & $\mathrm{MSc}$ & 44 & 62.0 \\
\hline & $\mathrm{PhD}$ & 1 & 1.4 \\
\hline \multirow{7}{*}{ Respondent's Profession } & Architect & 13 & 18.3 \\
\hline & Building Engineering & 3 & 4.2 \\
\hline & Civil/Structural Engineering & 14 & 19.7 \\
\hline & Electrical Engineering & 1 & 1.4 \\
\hline & Mechanical Engineering & 1 & 1.4 \\
\hline & Construction/Project Management & 24 & 33.8 \\
\hline & Quantity Surveying & 15 & 21.1 \\
\hline \multirow[t]{4}{*}{ Company’s specialization } & Contractor/Construction & 24 & 33.8 \\
\hline & Designer or Consultant & 37 & 52.1 \\
\hline & Client & 9 & 12.7 \\
\hline & Development Authority & 1 & 1.4 \\
\hline \multirow{4}{*}{$\begin{array}{l}\text { Size of technical personnel in the } \\
\text { Organisation }\end{array}$} & Less than 10 personnel (Micro) & 28 & 39.4 \\
\hline & 10-50 Personnel (Small) & 18 & 25.4 \\
\hline & 50-200 Personnel (Medium) & 4 & 5.6 \\
\hline & More than 200 personnel (Large) & 21 & 29.6 \\
\hline \multirow[t]{3}{*}{ Year of Experience } & $5-10$ years & 20 & 28.2 \\
\hline & $11-15$ years & 11 & 15.5 \\
\hline & $>15$ years & 40 & 56.3 \\
\hline \multirow[t]{5}{*}{ Continents of the participants } & Africa & 39 & 54.9 \\
\hline & Asia & 16 & 22.5 \\
\hline & Australia & 1 & 1.4 \\
\hline & Europe & 13 & 18.3 \\
\hline & North America & 2 & 2.8 \\
\hline
\end{tabular}

\section{RESULTS AND DISCUSSION}

From the result of the analyzing it's become clear from the project position that above 90 percent reported as the projects belong to them was impacted due the Epidemic. Nearly 51 percent of participants suggested that their initiatives were partly halted due to the COVID-19, while up to 40 percent of the participants witnessed full stoppage. One of the participants disclosed that the proposals had been absolutely halted at the first level after twisted into partial. Fascinatingly, others did not have the history with halting by saying that the process was restructured on a regular basis, based on the form of projects; the researcher gave insight that the knowledge of both filled stoppage and part stoppage. Some had to save an affected employee from witnessing it. A description of the quantitative data produced from the questionnaire survey is presented in Table 2. 
Table 2: Shows the description of the quantitative data produced

\begin{tabular}{|c|c|c|c|}
\hline Questions & Options/Descriptions & Frequencies & $\begin{array}{l}\text { Percentage } \\
(\%)\end{array}$ \\
\hline \multirow[t]{2}{*}{ Did COVID-19 affect your project? } & Yes & 69 & 97.2 \\
\hline & No & 2 & 2.8 \\
\hline \multirow{2}{*}{$\begin{array}{l}\text { Do you consider permanent changes to your working } \\
\text { process? }\end{array}$} & Yes & 42 & 59.2 \\
\hline & No & 29 & 40.8 \\
\hline \multirow{2}{*}{$\begin{array}{l}\text { In the face of the Pandemic, did you obtain or anticipate } \\
\text { getting any benefit from the government (e.g., tax or } \\
\text { VAT waver, furlough)? }\end{array}$} & Yes & 17 & 23.9 \\
\hline & No & 54 & 76.1 \\
\hline \multirow[t]{3}{*}{ In which way did COVID-19 affect your project(s)? } & Full stoppage & 29 & 40.8 \\
\hline & Partial stoppage & 36 & 50.7 \\
\hline & Others & 6 & 8.5 \\
\hline \multirow[t]{3}{*}{ What is the current status of your project(s)? } & $\begin{array}{l}\text { Work returned with } \\
\text { disruptions and progress } \\
\text { affected }\end{array}$ & 52 & 73.2 \\
\hline & Work has not returned & 13 & 18.3 \\
\hline & $\begin{array}{l}\text { Work returned without } \\
\text { affecting our weekly } \\
\text { progress }\end{array}$ & 6 & 8.5 \\
\hline \multirow[t]{4}{*}{ Reason(s) for suspension of work not resuming work? } & Government decision & 40 & 56.3 \\
\hline & Business decision & 14 & 19.7 \\
\hline & Personnel decision & 7 & 9.9 \\
\hline & Other reasons & 10 & 14.1 \\
\hline \multirow{5}{*}{$\begin{array}{l}\text { If COVID-19 affected your project, what is the level of } \\
\text { its impact on your workflow? }\end{array}$} & Severe & 11 & 15.5 \\
\hline & Major & 23 & 32.4 \\
\hline & Moderate & 27 & 38.0 \\
\hline & Minor & 5 & 7.0 \\
\hline & Insignificant & 5 & 7.0 \\
\hline \multirow{5}{*}{$\begin{array}{l}\text { Rate the impact of the lessons learnet on your projects / } \\
\text { business }\end{array}$} & Very significant & 0 & 0.00 \\
\hline & Significant & 24 & 33.8 \\
\hline & Average & 36 & 50.7 \\
\hline & Minor & 6 & 8.5 \\
\hline & Minimal & 5 & 7.0 \\
\hline
\end{tabular}

There was typically a great sign of relaxation as the easing of lockout approaches, as 73 percent suggested that job has resumed within delays and pretentious development. In contrast, approximately $8 \%$ reverted to work deprived of hindering the daily advancement of the job. Inappropriately, $18 \%$ already face a complete lockdown on their ventures. The job stoppage can be further verified in the building setting by means of (Ogunnusi et al. 2020) finding. In the grounds of a government order, 56 percent suggested that work was stopped while it was a company judgment for 14 participants. $10 \%$ of the respondents depend on their private preference. Other decisions may be the latest creation of "work from home." During this time, some of the governments in various states provided assistance bundles for industry sustenance support. For example, in the case of the United Kingdom, aid programs in the form of a tax or VAT waiver 
or furlough are given to multinational organizations to save the economy. Seventeen participants either suggested the reception or expected the government's acquisition of the grant, although 54 participants were not in a position to obtain those benefits. Thus, with more than 70 percent not benefiting from the government, this showed that the construction sector would not benefit from incentives and exemptions from other governments. In addition, there is significant doubt about the condition of the post-COVID-19 industry as opposed to other sectors that have benefited from such initiatives. Fig. 4 explains how the closing of building sites and their subsequent effects on construction developments have been impacted by government and business decisions. The government decision emerged in the wake of the COVID-19 pandemic as a significant explanation for the stoppage of work in the building sector. In addition, the government lockout decision is the key justification for the complete stoppage of on-site work and, where possible, for the partial stoppage of work complemented by homework and skeleton activities.

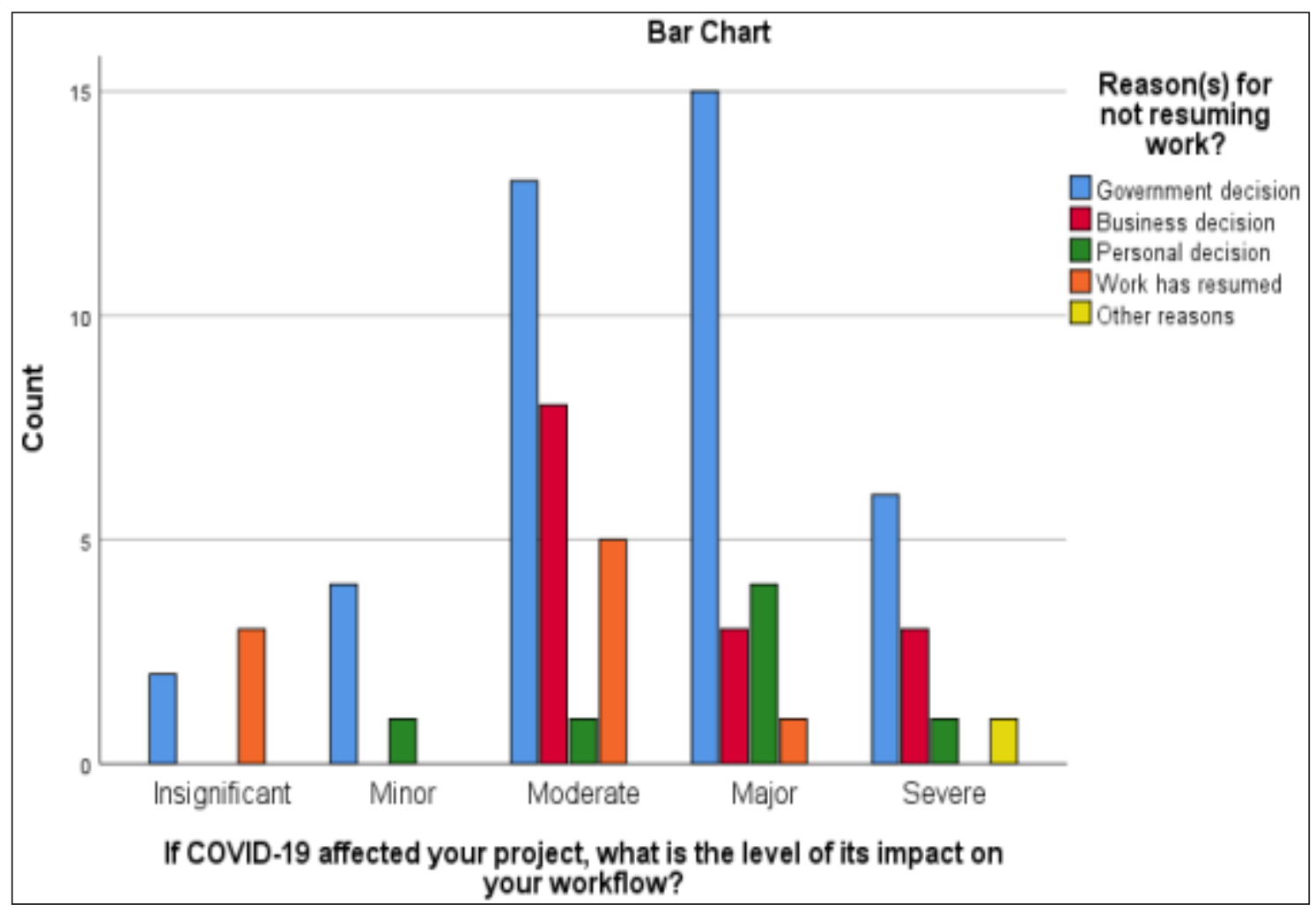

Fig. 4: Frequency vs Impact plot: Impact of work stoppage on projects and reason(s)

\section{CONCLUSION}

COVID-19 pandemic, building industry members, including founders, developers, contractors, subcontractors and supply chain suppliers, have endured differing degrees of impacts. In large part, the essence of the consequences and the magnitude of the implications depend on the position of both the relevant firms and the underlying programs. Direct impacts varied from the slowdown of supplies and labor available to suspensions and, in some situations, terminations of parties or programs as a whole. In 
certain states and cities, building operations remain in flux, depending on whether construction is classified as an important sector. In addition, there is significant doubt about the condition of the post-COVID-19 industry as opposed to other sectors that have benefited from such initiatives. Fig. 2 explains how the closing of building sites and their subsequent effects on construction developments have been impacted by government and business decisions. The government decision emerged in the wake of the COVID-19 pandemic as a significant explanation for the stoppage of work in the building sector. In addition, the government lockout decision is the key justification for the complete stoppage of on-site work and, where possible, for the partial stoppage of work complemented by homework and skeleton activities.

\section{Areas of Further Research}

The COVID-19 pandemic has prompted a full reconstruction within the commercial building sector of the globe job dynamics and procedures that will certainly be around for several months, or even years, to come. There are expectations that COVID-19 building specifications will begin to change as the situation progresses. As this occurs, there is a potential for more study into this scenario to explore what the long-lasting consequences of the pandemic will be.

\section{REFERENCES}

1. Benton. 2015. Circular Economy Scotland. London: UK.

2. Badu, E., Edwards, D.J., Owusu-Manu, D.G. and Brown, D. 2012. Barriers to the implementation of innovative financing (IF) of infrastructure. Financial Management of Property and Construction, pp. 253-273.

3. Chivilo, J.P., Fonte, G.A. and Koger, G.H. 2020. insights/publications. Retrieved from www.hklaw.com: https://www.hklaw.com/en/insights/publications/2020/05/a-look-at-covid19-impacts-on-the-constructionindustry

4. Daszak, P. 2012. Anatomy of a pandemic. helancet.com, 2.

5. European Commission. 2019. The European Green Deal; European Commission. Belgium: Brussels.

6. Gebeshuber, I.C., Gruber, P. and Drack, M. 2009. A gaze into the crystal ball: Biomimetics in the year 2059. Mechanical Engineering Science, 12.

7. Gopinath, G. 2020. blogs.imf.org/2020/03/09/limiting-the-economic-fallout-of-the-coronavirus. Retrieved from blogs.imf.org: https://blogs.imf.org/2020/03/09/limiting-the-economic-fallout-of-the-coronaviruswith-large-targeted-policies/

8. Górecki, J., Núñez-Cacho, P., Corpas-Iglesias, F. and Molina, V. 2019. How to convince players in construction market? Strategies for effective implementation of circular economy in construction sector. Cogent Eng., 6.

9. Hew, D. 2020. Press/Blogs. Retrieved from www.apec.org: https://www.apec.org/Press/Blogs/2020/0528 COVID. 
10. Hirschnitz-GarbersAdrian, M., TanAlbrecht, T.A. and Srebotnjak, G.S. 2015. Key drivers for unsustainable resource use - categories, effects and policy pointers. Cleaner Production in press, corrected proof, 15.

11. Lepora, N., Verschure, P.F. and Prescott, T.J. 2013. The state of the art in biomimetics. Bioinspiration \& Biomimetics, 8 .

12. Saunders, M. Lewis, and AThornhill, P. 2009. An Overview of Research Methodology in Information System (IS). Scieintific Research, 11.

13. Meng, X. 2013. Scalable Simple Random Sampling and Stratified Sampling. Semantic Sholar, 13.

14. Naidoo, R. and Fresher, B. 2020. Reset Sustainable Development Goals for a pandemic world. Nature, pp. 198-201.

15. Ogunnusi, Mercy, Mansur, Salman, Huda, Kouider and Tahar. 2020. COVID-19 Pandemic: The Effects and Prospects in the Construction Industry. COVID-19 Pandemic: The Effects and Prospects in the Construction Industry, 9.

16. Ott, \& Longnecker. 2001. An Introduction to Statistical Methods and Data Analysis. California: Duxbury Press.

17. Pourghasemi, H.R., Pouyan, S., Heidari, B., Farajzadeh, Z., Shamsi, S.R., Babaei, S. and HassanTarazka, M. 2020. A critical analysis of the impacts of COVID-19 on the global economy and ecosystems and opportunities for circular economy strategies. International Journal of Infectious Diseases, pp. 90-108.

18. Reike, D., J.V. Vermeulen, W. and Witjes, S. 2018. The circular economy: New or Refurbished as CE 3.0? - Exploring Controversies in the Conceptualization of the Circular Economy through a Focus on History and Resource Value Retention Options. Resources, Conservation and Recycling, pp. 246-264.

19. Schober, K.S. 2020. What the new normal could look like in construction. Retrieved from www. rolandberger.com: https:/www.rolandberger.com/en/Insights/Publications/What-the-new-normal-couldlook-like-in-construction.html

20. Schober, K.S. 2020. What-the-new-normal-could-look-like-in-construction. Retrieved from rolandberger. com: https://www.rolandberger.com/en/Insights/Publications/What-the-new-normal-could-look-like-inconstruction.html

21. Seebacher, G. and Winkler, H. 2013. A Citation Analysis of the Research on Manufacturing and Supply Chain Flexibility. Production Research, pp. 3415-3427.

22. Sohrabi, C., Alsafi, Z., O'Neill, N., Khan, M., Kerwan, A., Al-Jabir, A., . . Agha, R. 2020. World Health Organization declares global emergency: A review of the 2019 novel coronavirus (COVID-19). National Liburary of Midecine, pp. 71-76.

23. T.IbnMohammed, K.B.Mustapha, J.GodsellaZ.Adamu, K.A.Babatund, D.Akintade, A.Acquaye, . . . S.C.L.Koh. 2021. A critical analysis of the impacts of COVID-19 on the global economy and ecosystems and opportunities for circular economy strategies. Resources, Conservation and Recycling, 22.

24. Ward, E. 2020. Viewpoint. Retrieved from www.viewpoint.com: https://www.viewpoint.com/blog/ covid-19-impacts-on-the-construction-industry\#: : text=According $\% 20$ to $\% 20$ data $\% 20$ from $\% 20$ AGC,to $\% 20$ the $\% 20$ Covid $\% 2$ D19\%20outbreak.\&text=As $\% 20$ construction $\% 20$ projects $\% 20$ slow $\% 2$ C $\% 20$ workers,state $\% 20$ and $\% 20$ impacted $\% 20$ construction $\% 20$ projec 
